\title{
COHEN Monique Lise et SZAPIRO Élie, Histoire des communautés juives de Toulouse
}

\section{Gilles Ferréol}

\section{(2) OpenEdition \\ 1 Journals}

\section{Édition électronique}

URL : https://journals.openedition.org/remi/4042

DOI : $10.4000 /$ remi.4042

ISSN : $1777-5418$

Éditeur

Université de Poitiers

\section{Édition imprimée}

Date de publication : 1 septembre 2004

Pagination : 195-196

ISBN : 2-911627-37-7

ISSN : 0765-0752

\section{Référence électronique}

Gilles Ferréol, «COHEN Monique Lise et SZAPIRO Élie, Histoire des communautés juives de Toulouse », Revue européenne des migrations internationales [En ligne], vol. 20 - n² | 2004, mis en ligne le 25 septembre 2008, consulté le 16 avril 2022. URL : http://journals.openedition.org/remi/4042 ; DOI : https://doi.org/10.4000/remi.4042

Ce document a été généré automatiquement le 16 avril 2022.

(c) Université de Poitiers 


\title{
COHEN Monique Lise et SZAPIRO Élie, Histoire des communautés juives de Toulouse
}

\author{
Gilles Ferréol
}

\section{RÉFÉRENCE}

COHEN Monique Lise et SZAPIRO Élie, Histoire des communautés juives de Toulouse, Portetsur-Garonne, Loubatières, 2003, 112 p., 14 euros. ISBN : 2-86266-371-9.

1 Dès le Moyen Âge, rappellent à juste titre les auteurs, le Languedoc fut une terre accueillante et privilégiée pour les Juifs. Aux temps épanouis de la civilisation méridionale, ceux-ci - jetant un pont entre l'Orient et l'Occident - y développèrent, les écrits de Benjamin de Tudèle en témoignent, une importante activité économique, comme à Narbonne qui fut la plaque tournante d'un commerce international vers l'est de l'Europe, l'Italie, l'Afrique du Nord, le Levant, la Perse et la Chine. Cependant, après l'annexion du Midi au domaine royal, leur situation se dégrada jusqu'aux expulsions de 1306, 1322 et 1394.

2 Parmi les passages les plus intéressants, signalons ceux relatifs aux pratiques de colaphisation (" avanie rituelle qui consistait à donner un soufflet aux représentants de cette communauté devant la porte de la principale église, le Vendredi saint, [...] afin de venger la mort du christ », p. 23) ou au Code de l'inquisition tel que l'avaient édicté Bernard Gui puis Nicolas Eymerich, au massacre des Pastoureaux ou à la religion marrane («sorte de judaïsme déformé par l'environnement chrétien», p.39), sans oublier le rapport à l'autre, le mythe de l'errance ou bien encore la légende de la fondation des Carmes (pp. 101-103).

3 La Renaissance fait également l'objet d'un examen attentif: le scepticisme, en particulier, y est à l'honneur à travers les portraits de Montaigne et de Francisco Sanchez, les problèmes d'intégration étant au cœur de la réflexion. Autre période mise 
en valeur : la fin du XIX et le début du XX ${ }^{\mathrm{e}}$ siècle. Sont notamment évoqués l'affaire Dreyfus, l'impact des Protocoles des Sages de Sion, "pièce à conviction de tous les antisémites » (p. 65), ainsi que la destinée de personnalités de premier rang comme le philosophe Frédéric Rauh ou le poète symboliste Ephraïm Mikhaël. La Seconde Guerre mondiale, enfin, avec ses horreurs, ses persécutions et ses camps d'internement, n'est évidemment pas oubliée, de très belles pages faisant l'éloge des grandes figures de la Résistance toulousaine tels Sarah-Ariane Fixman-Knout, les rabbins Cassorla et Hosanski.

4 Toute cette histoire, on l'aura compris, ne se joue pas nécessairement dans le bruit et la fureur mais "s'invente dans l'écriture, dans la lecture, dans notre effort de parole » (p. 108).

\section{AUTEURS}

GILLES FERRÉOL

Université de Poitiers (LARESCO-ICOTEM) 